\title{
PATRIMONIAL RESOURCES MANAGEMENT AND THE ECONOMIC PERFORMANCE OF COMPANIES
}

\author{
Camelia Burja ${ }^{1}$
}

\begin{abstract}
Achieving high performance is a crucial objective aimed by the management of any company. The accurate and efficient economic resources management contributes decisively to improving performance. The paper presents an econometric model that shows the link between economic performance and patrimony management reflected through a series of indicators, such as the return on current assets, fixed assets ratio and the funding structure of capitals (financial leverage). In terms of research tools, we used techniques of regression analysis based on specialized software. The obtained results allow drawing conclusions about the elements upon which decision makers should intervene in order to increase economic performance.
\end{abstract}

Key words: economic performance, regression analysis, modelling, patrimony management

JEL codes: L25, M11

\section{Introduction}

Information about the economic performance achieved by companies is useful for managers and investors to satisfy the earning interest. Performance analysis allows the assessment of potential changes in the economic resources that the enterprise will be able to control in the future and it also allows to anticipate the ability to generate positive cash flows.

Achieving high economic performance involves increasing the marginal profit of the used resources. To comply with this principle is necessary to guide management decisions towards actions that increase financial results through effective use of every available resource.

The main objective of this study is to identify the dependency relation between the patrimonial resources management of companies and economic performance. Information from financial statements of a representative company from Romanian agriculture for the period between 2000 and 2009 were used to achieve the aimed goal.

Fixed assets, current assets, shareholders' equity and debts were selected for research of the patrimony resources used by the company to achieve its objective. We believe the efficient management of these production factors creates the circumstances for the improvement of financial resources.

Financial analysis indicators expressed by Return on Current Assets, Fixed Assets Ratio and Debts/Equity Ratio are developed to analyze the efficiency of patrimonial resources. These indicators represent the main exogenous variables included in the regression analysis model. The influence of these variables' action on profit is represented by the form of the multi-factorial regression equation obtained by using the Eviews software.

The validation of the econometric model proposed in this paper is based on the main statistical tests applied to the obtained regression coefficients, variables and model as a whole. The results suggest that in the case of the analyzed company, the profitability of current assets and the funding structure are elements with a significant impact over performance. The model presented by

\footnotetext{
1 „1 Decembrie 1918” University of Alba Iulia, Faculty of Science, Romania, e-mail: cameliaburja@yahoo.com
} 
the paper helps financial management in analyzing economic performance and allows the identification of phenomena that are significant for corporate efficiency.

\section{Literature review}

The economic performance of a company is often proved by its profitability. Profitability is the ultimate goal of corporate activity and the main condition to exist and remain on the market within a competitive economy. Thus, the analysis of profitability occupies an essential position within the diagnosis of economic performance (Burja and Burja, 2010).

A useful tool in studying profitability and changes occurred from one reporting period to another are the economic and financial analysis techniques applied within determinist models. These models highlight how results are obtained during the current activity of companies, their size, the absolute and relative dynamic, the impact of various influence factors over profitability, etc. All this information are of interest for various external beneficiaries and for the companies' management (planning, control, decision, performance assessment) (Keller, 2008). At the level of companies, the data obtained from financial analysis provide substantiation of managerial decisions regarding the operative adjusting of economic processes for a better allocation and use of production factors.

Another method to study profitability is regression analysis, which allows shaping the functional form of dependency among various economic and financial indicators. Modelling economic performance aims to increase efficiency by improving interventions in the adaptivelearning cycle (Campbell et al., 2001). The models intended for studying the impact of allocation and use of capital within the company ties performance to the contribution of various resources at the improvement of efficiency, expressed in terms of profitability (Dumbravă, 2010).

The indicators involved in regression analysis of economic performance are many. In recent literature, the profitability of companies in various countries and economy sectors is expressed by indicators like: Net Operating Profitability (NOP), (Raheman et al., 2010), (Dong et al., 2010), Return on Total Assets (ROTA) (Deloof, 2003), (Padachi, 2006), Return on Invested Capital (ROIC), Return on Assets (ROA) (Narware, 2010). The elements taken into account in the analysis as independent variables express the management of the working capital.

For Romania, in the case of companies listed on the stock market, the econometric models highlight the correlation between intangible assets and company performance, expressed by average market price, price/earnings ratio and earnings per share (Purcărea et al., 2008). Other models express the correlation between net profit and cash-flow for profitability analysis (Matis et al., 2010).

\section{Methodology and the analysis framework of performance}

In this paper, we conducted an analysis of the financial situation of a company operating in agriculture within a specified timeframe. Regression analysis aimed to identify the factors with a determining role in the manifestation and evolution of profit.

The multiple regression model is expressed as a functional connection between a dependent variable $(Y)$ and a series of $k$ independent variables $\left(X_{i}\right)$, which play a key role in the manifestation of the resulted phenomenon trend. The action of random factors is introduced in the model through residual variables $\varepsilon$ (Anderson et al., 2007):

$$
Y=f\left(X_{i)}+\varepsilon \quad i=1, . . k\right.
$$

The net profit was chosen as dependent variable in order to conduct regression analysis of performance, which synthetically expresses the activity's profitability. It is formed through the combined action of various financial flows obtained from the use of assets and encashment of incomes mainly achieved from commercialisation of the production. Therefore, performance 
analysis may be conducted on the basis of profit, which is seen as a variable dependent on the efficient management of the used assets (Burja, 2009).

An important element that influences the economic performance of companies is the profitability of current assets. It depends on the efficiency of stocks and receivables. Stocks and receivables are elements where a part of the financial capital is immobilized until they are recovered in revenue. Their management should be based on criteria of economic efficiency (Schim et al., 2009) and may be expresses by the Return on Current Assets (ROCA) indicator:

$$
\text { ROCA }=\frac{\text { Profit }}{\text { Current.assets }}
$$

The Debts/Equity Ratio (DER) indicator is the financial leverage measure of a company. The elements that are included in the calculus of $D E R$ express the main financial sources that must be obtained and used to produce goods that generate value. For this reason, by creating certain correlations between financing sources, a more advantageous financing of the operations may be stimulated and, thus, increase economic performance. Financial leverage may generate profit by achieving a higher return from operating activities than the paid interest rate for loans (Helfert, 2002). It's calculated as follows:

$$
D E R=\frac{\text { Debts }}{\text { Equity }}
$$

The Fixed Asset Ratio (FAR) is the result of the investment policy practiced by the firm. Its increase will help achieving an additional production capacity. It is calculated as follows:

$$
F A R=\frac{\text { Fixed Asset }}{\text { Total Asset }}
$$

By customizing equation (1) for the analysis of absolute profitability, a model with several factors emerges, in which the dependent variable (endogenous) is the achieved profit and the independent variables (exogenous) are the turnover, as well as a series of assessment indicators for the efficient use of patrimony elements.

By approaching the functional form of the dependence relationships between variables as a linear multi-factorial equation, the analysis model becomes:

$$
N I_{i}=\beta_{0}+\beta_{1} N S_{i}+\beta_{2} R O C A_{i}+\beta_{3} F A R_{i}+\beta_{4} D E R_{i}+\varepsilon_{i} \quad i=1, \ldots, n
$$

where: NI represents Net Income;

$N S \quad-\quad$ Net Sales;

ROCA - Return on Current Assets;

FAR - Fixed Asset Ratio;

DER - Debts/Equity Ratio;

$\varepsilon \quad-\quad$ Residual variable, the parameter that expresses the variation level of the dependent variable depending on the action of factors that weren't included in the model;

$\beta_{0} \quad$ - $\quad$ Regression constant (intercept);

$\beta_{1}, \beta_{2}, \beta_{3}, \beta_{4}$ - Regression coefficients for independent variables (model parameters). 
The partial coefficients of regression $\beta_{1}, \beta_{2}, \beta_{3}, \beta_{4}$ express the increase of the NI dependent variable's size at the increase by one unit of the corresponding estimated variable when all the other variables are constant. The coefficients identified in the model provide the extent of the influence of each factorial variable over the endogenous variable and express the marginal profit achieved from patrimony management.

A necessary stage preceding the actual resolution of the model is checking its accuracy on the basis of the characterization hypotheses of the parameters, residuals and overall quality of regression. Standard hypotheses refer to the linear functional form, the zero average of errors (residuals), the presence of homoskedasticity, uncorelation of errors, the normal distribution of errors, the lack of collinearity of exogenous variables, the significance level of variables (Andrei et al., 2008). In case of deviations from the fundamental hypotheses, there are specific treatments that improve the model and can lead to solving it on the basis of the method of least squares.

The analyzed data include a group of indicators that reflect the patrimony statement of an agricultural company for the period 2000-2009 (table no.1).

Economic and financial indicators, 2000-2009 (thousand lei)

\begin{tabular}{|c|c|c|c|c|c|c|c|c|}
\hline Year & $\begin{array}{c}\text { Fixed } \\
\text { assets }\end{array}$ & $\begin{array}{c}\text { Current } \\
\text { assets }\end{array}$ & Inventory & $\begin{array}{c}\text { Accounts } \\
\text { Receivable }\end{array}$ & $\begin{array}{c}\text { Shareholders' } \\
\text { equity }\end{array}$ & Debts & Net sales & $\begin{array}{c}\text { Net } \\
\text { Income }\end{array}$ \\
\hline 2000 & 8679.0 & 25980,7 & 14355.7 & 4890.2 & 9230.8 & 25428.9 & 28437.8 & 3278.6 \\
\hline 2001 & 9278.9 & 28190,3 & 15890.8 & 5799.9 & 10970.2 & 26499.0 & 30550.8 & 3518.9 \\
\hline 2002 & 10250.9 & 28970.9 & 16343.8 & 6760.6 & 11678.9 & 27542.8 & 32869.0 & 3458.8 \\
\hline 2003 & 11456.5 & 30678.0 & 17868.0 & 7490.0 & 12680.2 & 29454.3 & 38907.6 & 4148.9 \\
\hline 2005 & 12239.0 & 34088.9 & 19215.2 & 6053.2 & 12085.2 & 34242.7 & 57977.7 & 5236.6 \\
\hline 2005 & 32086.8 & 52516.7 & 29831.0 & 13002.5 & 33541.6 & 51061.9 & 63600.2 & 13276.1 \\
\hline 2006 & 35857.9 & 70282.0 & 40756.3 & 28605.1 & 47898.4 & 58241.5 & 74228.6 & 14856.8 \\
\hline 2007 & 42745.7 & 99319.7 & 46188.9 & 39697.1 & 54934.0 & 87131.4 & 83030.6 & 8035.6 \\
\hline 2008 & 45925.9 & 100000.0 & 48466.6 & 21143.1 & 55444.1 & 98158.4 & 105163.0 & 5949.2 \\
\hline 2009 & 49740.7 & 85635.9 & 46026.9 & 38442.9 & 54594.7 & 80781.9 & 89198.0 & 3471.0 \\
\hline
\end{tabular}

Source: financial statements of the company

Descriptive statistics of the model variables (table no.2) provide information about the average indicators and the variation of the characteristics belonging to the series of data that will be used.

Table no. 2

\section{Descriptive statistics of variables}

\begin{tabular}{|l|c|c|c|c|}
\hline Variables & Mean & Max & Min & Std. deviation \\
\hline$N S$, thousand lei & 60396.3 & 105000.0 & 28437.8 & 27253.9 \\
\hline$R O C A$ & 0.1300 & 0.2528 & 0.0405 & 0.0653 \\
\hline FAR & 0.2980 & 0.3797 & 0.2476 & 0.0483 \\
\hline $1 / D E R=$ Equity/Debs & 0.5335 & 0.8224 & 0.3529 & 0.1591 \\
\hline$D E R$ & 2.0259 & 2.8334 & 1.2159 & 0.5774 \\
\hline
\end{tabular}

Source: results of Eviews 7.1

The relatively low level of Fixed Asset Ratio shows the specific of the activity, which is agriculture. Debts/Equity Ratio had an average of 2, a maximum of 2.8 and an average variation of 
0.58. This structure of capitals practiced by the company shows that it financed its development mostly through loans, taking a financial risk. Therefore, it is considered that the financial autonomy was affected. Having an Equity/Debts ratio of approximately $50 \%$ and a maximum of $82.2 \%$, it is believed the company had a satisfying reliability level.

The analysis of correlations between exogenous variables shows the existence of significant connections between some variables (table no.3).

Table no. 3

\begin{tabular}{|l|c|c|c|c|}
\hline & ROCA & 1/DER & NS & FAR \\
\hline ROCA & 1.000000 & 0.175769 & -0.319169 & 0.235471 \\
\hline I/DER & 0.175769 & 1.000000 & 0.585819 & 0.848287 \\
\hline NS & -0.319169 & 0.585819 & 1.000000 & 0.541283 \\
\hline FAR & 0.235471 & 0.848287 & 0.541283 & 1.000000 \\
\hline
\end{tabular}

Source: Eviews 7.1

The strongest dependence exists between Fixed Assets Ratio $(F A R)$ and Debts/Equity Ratio $(1 / D E R)$ for which the correlation coefficient is 0.848 . The close connection between these two indicators is normal. When the financial autonomy rate (Equity/Debts) increases by changing the structure of the financing sources, the share of fixed assets also increases, which shows that the company invests its capital in the technical and production base to increase the production capacity. The other variables have important correlation coefficients, but they are under the value of 0.7 , which is considered critical (Anderson et al., 2007).

Although the economic content of correlations between independent variables is accurate from a statistical viewpoint, the existence of correlation coefficients close to 1 signals the presence of potential collinearity between variables.

The manifestation of the multi-collinearity phenomenon leads to a lower degree of accuracy for estimates, because when small changes occur in the input data, the regression coefficients are significantly altered. However, multi-collinearity doesn't affect the forecasting power and the reliability of the model, it remains valid at least for the data series used in the analysis.

A criterion that may identify collinearity is the Klein criterion. Two exogenous variables will be considered collinear if they comply simultaneously with two conditions, namely they have a correlation coefficient $\left(r_{x_{i} / x_{j}}\right)$ that is significantly different from zero and $r_{x_{i} / x_{j}}^{2}$ is higher than the relation that determines the regression model $\left(R_{Y}^{2}\right)$ (Tudorel, 2008).

\section{The empirical regression model for performance valuation}

Using specialized software, Eviews, to solve the model (equation 2) leads to obtaining the regression equation with the specified parameters. The statistical data characteristic for regression are presented in table no.4.

Table no. 4

\section{Characteristics of the regression model}

\begin{tabular}{|c|c|c|c|c|}
\hline $\begin{array}{c}\text { Independent } \\
\text { variables }\end{array}$ & $\begin{array}{l}\text { Regression } \\
\text { coefficients }\end{array}$ & t-Statistic & $\begin{array}{l}\text { Probabi } \\
\text { lity }\end{array}$ & Model quality \\
\hline ROCA & 53173.47 & 10.98051 & 0.0001 & $\mathrm{R}^{2} 0,985$ \\
\hline $1 / D E R$ & 16629.09 & 5.499635 & 0.0027 & $\mathrm{R}^{2}$ adjust 0,973 \\
\hline$N S$ & 0.0674 & 4.297890 & 0.0077 & Fstat 83,08 \\
\hline$F A R$ & -30827.68 & -3.166291 & 0.0249 & Prob(F-statistic) 0,0000 \\
\hline
\end{tabular}


Source: results from Eviews 7.1

The obtained results lead to the next equation, which describes the dependency between the profit of the analyzed company and the management of the patrimony elements:

$$
N I=-4145.35+0.0674 \cdot N S+53173.47 \cdot R O C A+16629.09 \cdot \frac{1}{D E R}-30827.68 \cdot F A R
$$

Accepting the identified econometric model depends on a series of statistical tests which will conclude on its accurateness and reliability for future economic analyses related to the activity of the company.

A necessary verification stage is studying overall performance of the model based on the information provided by relation $R_{y}^{2}$.

Table 4 shows a strong determining relation that indicates in a proportion of $97.3 \%$ the dependent phenomenon meaning the profit of the company is determined by exogenous variables (NS, ROCA, DER, FAR).

The relation $r_{x_{i} / x_{j}}^{2}<R_{y}^{2}$ (the higher correlation coefficient is 0.848 and $r_{x_{i} / x_{j}}^{2}=0.719$ <0.985) is verified for any correlation coefficients $r_{x_{i} / x_{j}}$, which removes to a certain extent the suspicion related to the existence of a perfect linear relationship between exogenous variables. However, the high value of the determining relation seems to suggest an imperfect collinearity relationship.

One way to reduce collinearity is the mechanical removal of those variables that have a strong connection with the others, such as Fixed Asset Ratio and Debts/Equity Ratio (Voineagu et al., 2006). The waived variable is $F A R$, and the result was a changed regression model (table no.5 and equation 6).

Table no. 5

Characteristics of the modified regression model

\begin{tabular}{|l|r|r|r|l|}
\hline $\begin{array}{c}\text { Independent } \\
\text { variables }\end{array}$ & $\begin{array}{c}\text { Regression } \\
\text { coefficients }\end{array}$ & t-Statistic & $\begin{array}{c}\text { Probabi } \\
\text { lity }\end{array}$ & \multicolumn{1}{|c|}{ Model quality } \\
\hline ROCA & 48053.75 & 6.652532 & 0.0006 & $\mathrm{R}^{2} 0,955$ \\
\cline { 2 - 4 } $\mathrm{R}^{2}$ adjust 0,933 \\
\cline { 1 - 3 }$N S$ & 3928.38 & 2.842239 & 0.0295 & $\begin{array}{l}\text { Fstat 42,90 } \\
\text { Prob. (F-statistic) } 0,0001\end{array}$ \\
\hline
\end{tabular}

Source: results of Eviews 7.1

$$
N I=-8666.43+0.051 \cdot N S+48053.75 \cdot R O C A+10980.77 \cdot \frac{1}{D E R}(6)
$$

The Fisher Snedecor $(F)$ statistic is used to assess the validity of the transformed model that characterizes the dependency between profit and independent variables. For a significance level of $\alpha=0.05$, results $F_{\text {calc }}=42.9>F_{0.05 ; 3 ; 6}=4.76$, which suggests the model is valid.

The value $t$ is used to test the coefficients' significance of the obtained regression model, the sample's volume being reduced $(n<30)$ (Cadoret et al., 2004). For a $\alpha=0.05$ and six degrees of freedom, the theoretical value of distribution $t$-Student is $t_{0.05 ; 6}=1.94$. For all the regression 
coefficients, the calculated value of $t$ exceeds the critical value, which shows the parameters are significant and have a $95 \%$ probability to guarantee results.

$$
\left|t_{N S}\right|,\left|t_{R O C A}\right|,\left|t_{1} / \mathrm{DER}\right|>t_{0.05 ; 6}=1.94
$$

In these circumstances, it may be said the independent variables taken into account by the model influence the analyzed dependent phenomenon.

The analysis stage of the errors is based on the idea that an adequate econometric model must show low or zero correlation of with the residual variable, of constant variance and normal distribution; otherwise, the model doesn't comply with the standard hypotheses, which determines an unsatisfactory quality for the forecasting of the phenomenon (Barrow, 2009).

The Breusch-Pagan-Godfrey test is used to detect the heteroskesdasticity situation for the calculus of the Lagrange Multiplier $(L M)$ value. This test checks if the estimated variance of the residuals is dependent on the value of the independent variables, under the null hypothesis $\left(\mathrm{H}_{0}\right)$ of homoskedasticity. If $L M_{c a l c}>\chi_{\alpha, k}^{2}$ ( $k$ number of parameters in the model), the null hypothesis $\left(\mathrm{H}_{0}\right)$ is rejected (Andrei, 2008). Because the Obs*R-squared indicator of the Eviews application indicates the value $L M_{\text {calc }}=5.76$, the calculated value is lower than the theoretical value $\chi_{0.05 ; 3}^{2}$ of 7.81. Therefore, the result of the test indicates the acceptance of the null hypothesis and the compliance with the homoskedasticity condition.

Another test necessary to verify the model refers to the normal distribution of random variables. For the proposed model, the histogram of the residual factors has a normal distribution.

The validation of the residual factors' term is done also on the basis of the Breusch-Godfrey test, which provides information about the autocorrelation of errors. The Lagrange Multiplier test and $F$ test shows that the errors are not correlated.

Testing the quality of the identified econometric model has shown its suitability for the studied phenomenon. The profit of the analyzed company for the period 2000-2009 may be expressed at a rate of $93.3 \%$ based on the influence factors, such as: Return on Current Assets, net sales and financial structure.

The dependency relationship between profit and the efficiency of current assets is direct, so that during the analyzed period this factor contributed to increasing the average profit. The size of the regression coefficient correspondent to Return on Current Assets (ROCA) shows the margin profit in accordance to this influence factor, which shows that through the unitary improvement of return on current assets, the profit can be increased by 48 million lei.

Sales have a low impact on profit growth. A favourable influence over profitability is exercised by the financing method of assets. On this basis, the profit has growth reserves of approximately 11 million lei.

\section{Discussion and conclusions}

The manifestation of performance at microeconomic level has specific particularities resulted from conditioned relationships that include value-generating assets.

Considering the aimed objective, namely to study the impact of patrimonial resources management over company performance, the first stage identified an econometric model where performance is expressed by the profit indicator and its main determining factors which are elements that influence the efficient management of assets, such as: Net Sales, Return on Current Assets, Fixed Asset Ratio and Debts/Equity Ratio.

A series of corrections and transformations of variables were performed to improve the quality of the model. These changes aimed to reduce the probability of imperfect collinearity of the 
independent variables. In the end, we obtained a regression model with higher economic and statistic quality that may be used in the performance analysis of agricultural activities.

The new resulted model expresses the dependency between profit and variables as efficiency of using current assets, sales and practiced financing structure.

An important factor of profit growth is to increase the efficiency use of all the current assets. However, improving profitability depends also on the set of funding sources and on the correlation established between own sources and borrowed sources. The proper management of the relation between the two main funding sources can improve the ability of the company to meet long term obligations, increase reliability and financial security, and therefore increase the ability of all the assets to generate positive effects. Thus, as in the case of the analyzed company, a way to improve performance, reduce debts and increase shareholders' equity emerges. Also, the firm's profitability receives qualitative parameters by promoting operational and strategic decisions that will lead to better management of the used assets, as well as of the funding sources.

Applying the econometric model in economic analyses for other companies or in agriculture requires additional verification tests, conducted by using new databases.

Reviewing the key economic and statistical aspects of the regression model for future research may suggest the introduction of new explanatory variables that will show in a more complex manner the performance of companies. Increasing its generality level for various activity sectors will allow achieving estimates assorted with reality, which will underpin the decisionmaking processes to increase performance.

\section{References}

1. Anderson D.R., Sweeney D.J., Williams T.A., 2007. Statistiques pour l'economie et la gestion, Editions De Boeck, Bruxelles.

2. Andrei T., Bourbonnais R., 2008. Econometrics, Economică Publishing House, Bucharest.

3. Barrow M., 2009. Statistics for Economics, Accounting and Business Studies, Pearson Education Limited, England.

4. Black K., 2010. Business Statitics for Contemporary Decisions Making, sixth edition, USA.

5. Burja C., 2009. Economic and Financial Analysis, Methodological Aspects and Practical Applications, Casa Cărții de Ştiință Publihing House, Cluj-Napoca.

6. Burja V., Burja C., 2010. Patrimonial Resources' Management And Effects On The Economic Value Added, Annales Universitatis Apulensis, vol.2, issue 12, pp. 608-615.

7. Cadoret I., Benjamin C., Martin F., Herrard N., Tanguy S., 2004. Econometrie appliquee methodes-applications-corigges, Editions De Boeck, Bruxelles.

8. Campbell B.M., Sayer J.A., Frost P., Vermeulen S. Ruiz Perez M., Cunningham A.B., Prabhu R., 2001. Assessing the performance of natural resource system, Conservation ecology, vol.5, 2001.

9. Deloof M., 2003. Does Working Capital Management Affect Profitability of Belgian Firms?, Journal of Business\&Accounting, vol.30, issue 3-4.

10. Dong H.P., Su J., 2010. The relationship between working capital management and profitability: a Vietnam case, International Research Journal of Finance and Economics, issue 49.

11. Dumbravă M., 2010. Company Performance Analysis: methods and model Analiza, Economică Publishing House, Bucharest.

12. Helfert E. A., 2002. Techniques of Financial Analysis: a Guide to Value Creation, McGrawHill Education.

13. Keller G., 2008. Statistics for Management and Economics, South-Western Cengage Learning, USA. 
14. Matis D., Vladu A.B., Negrea L., Sucala L., Jones, Dechow and Kasznik, 2010. Models Significance in the Romanian Economic Environment, Annales Universitatis Apulensis Series Oeconomica, vol. 1 issue 12.

15. Narware P.C., 2010. Working Capital Management: The Effect of Market Valuation and Profitability in Malaysia, International Journal of Business and Management, vol. 5, no. 11.

16. Padachi K., 2006. Trends in Working Capital Management and its Impact on Firms' Performance: An Analysis of Mauritian Small Manufacturing Firms, International Review of Business Research Papers, vol.2, no. 2, pp. 45 -58.

17. Purcărea I.I. Stancu I., 2008. The influence of R\&D Policy on Performance of the Companies Listed with Bucharest Stoch Exchange (through Intangible Assets), THeoretical and Applied Economics, AGER, vol. 11(528).

18. Raheman A., Afza T., Qayyum A., Bodla M.A., 2010. Working Capital Management and Corporate Performance of Manufacturing Sector in Pakistan, International Research Journal of Finance and Economics, issue 47.

19. Schim J., Siegel J., 2009. Schaum's outline of Advanced Financial Management, Third Edition, The McGraw-Hill Companies, UK.

20. Voineagu V., Țiţan E., Şerban R., Ghiţă S., Todose D., Boboc C., Pele D., 2007. Econometric Theory and Practice, Meteor Press Publishing House, Bucharest. 